\title{
WHEN IS A FIXED SUM NOT A FIXED SUM BUT A PENALTY CLAUSE?
}

\author{
Bruno Zeller*
}

\section{INTRODUCTION}

Professor Graves in his article Penalty Clauses and the CISG ${ }^{1}$ provides a response to the view that penalty clauses are governed by the CISG. ${ }^{2} \mathrm{He}$ argues very powerfully that penalty clauses are not to be governed by the CISG, as they do not overcome the Article 4 hurdles. Furthermore, he states that the purpose of his article is "to explore and evaluate these newly suggested rationalisations for diverging from the traditional view, as well as the original basis and continuing vitality of the traditional view." ${ }^{3}$

It should be noted that the CISG in its inception created a new approach to contract law by formulating a uniform law that is not dependent on domestic law. Article 7 and the Preamble clearly set out the aspirations and functions of the CISG. However, at the same time it must also be recognised that not all issues could be harmonised; hence there are gaps in the CISG that must be filled by domestic law, but only as a last resort if a close reading within the fours corners of the CISG do not offer a solution.

Therefore it is argued that whether a view is traditional or not is irrelevant. The question at the heart of the problem is whether general principles can cover a perceived gap and hence bring the issue within the domain of the CISG.

This article restates the views that fixed sums whether penal or not are governed by the CISG. It is admitted that Professor Graves does have some valid arguments that are in parts convincing, but still does not negate the issues at hand. It is argued that the argument in the end hinges on the position one takes to view contractual obligations. In other words, it depends whether

* Dr. Bruno Zeller is an Associate Professor, Victoria University, Adjunct Professor, School of Law, Murdoch University-Perth and an Associate, The Institute for Logistics and Supply Chain Management, Victoria University Melbourne.

1. Jack Graves, Penalty Clauses and the CISG, 30 J.L. \& Com. 153 (2012).

2. Bruno Zeller, Penalty Clauses: Are They Governed by the CISG?, 23 PACE INT'L L. Rev. 1 (2011), available at http://digitalcommons.pace.edu/pilr/vol23/iss1/1.

3. Graves, supra note 1, at 156. 
contracts are viewed from a "mercantile" rather than a "promissory" perspective. The central question is whether the validity issue is determined at the formation stage of a contract or when the contract is breached.

Professor Graves noted that the "validity exception" of Article 4(a)" is limited by its introductory clause "except as otherwise expressly provided in this convention." 4 However, even if there are issues that potentially could invoke Article 4, the "interpretation of validity is not initially a question of domestic law." The CISG "dictates the understanding of validity in the international context of a transaction and detached from national perceptions on the matter in order to avoid diverging results"6 which are exhibited in the treatment of fixed sums. Common law and civil law approaches to fixed sums are divergent and hence provide divergent results.

The desire to produce a harmonised law wherever possible is confirmed by Article 7(1), which directs the reader to the interpretation ladder in order to fill "internal gaps." So far this author and Jack Graves are at idem. The divergence of arguments is based on the fact that Graves argues that there is "no functionally adequate solution" to the issue. ${ }^{7}$ This argument is dependent on the fact that Article 6 cannot be invoked and hence Article 74 is applicable in its entirety as well as the fact that Article 4 is applied at the point when a party breaches the contract and not at the formation stage.

Two observations need to be made. First, the purpose of the CISG and indeed any convention is to introduce a uniform law into areas which otherwise are divergent. As it is noted, civil law countries do generally enforce penalty clauses; hence Article 4 is not enlivened and the CISG will govern the issue. In Australia, the issue is that penalty clauses are not enforceable and hence arguably again do not touch upon Article 4. The situation in the U.S. appears to be clear that penalty clauses are void; hence Article 4 could potentially be brought into play. It is therefore obvious that depending on the conflict of law rules in some circumstances the CISG will govern the issue whereas especially in U.S. jurisdictions the issue of validity needs to be tackled. Furthermore, the jurisprudence of this issue is varied. It is not surprising that in civil law countries the inclusion of a fixed sum that might be penal in nature is considered to be part of the CISG. Of special interest are

4. Id. at 157

5. Milena Djordjevic, Article 4, in UN Convention on Contracts for the International SAle OF Goods (CISG) 62, 69 (Stefan Kröll et al. eds., 2011).

6. $\quad I d$. at 68 .

7. Graves, supra note 1, at 161-62. 
recent decisions of courts in the Balkans. In the Trolleybus Case the Tribunal noted:

When deciding on [Buyer]'s claim for contractual penalty, the Tribunal took into consideration that the purpose of this penalty is to give an advance assessment of the amount of the damages for breach of contract. In other words, the creditor does not have to prove the existence of loss and its amount but only that the debtor failed to fulfil its obligation. $^{8}$

Furthermore, the Tribunal in the Milk Packaging Equipment Case stated clearly:

The Vienna Convention does not deal with the question of validity of the provision on liquidated damages, which are requested by the [Seller]; however, in accordance with the principle of party autonomy (Article 6 of the Convention), it is undisputed that the Convention allows the parties to freely determine the amount of compensation to be paid by the debtor to the creditor in case of non-performance or untimely performance of a contractual obligation. ${ }^{9}$

In sum it has been argued that:

It is evident from the rationales of these awards that agreeing to contractual penalties provisions had the sole purpose of estimating future damages and that the tribunals showed willingness to uphold such clauses where this was the case. ${ }^{10}$

Considering that the purpose of the CISG is to harmonise international sales laws, the issue of fixed sums is a prime example where a careful analysis is warranted in order to clarify and unify the law on this particular issue.

The second observation is that freedom of contract is a principle common to most if not all legal systems; hence it might be classed as a "sacred cow." Because these two principles, freedom of contract and harmonisation of laws, are of "primary" importance, it is argued that the CISG needs to be viewed from a global point of view as contained in Article 7. This requires a detailed examination of the CISG in order to point to a general principle that governs the issue at hand, namely the inclusion of fixed sum clauses. Because the

8. Foreign Trade Court of Arbitration attached to the Serbian Chamber of Commerce, Serbia, 30 Oct. 2006, at § VII, para. 8.3, available at http://cisgw3.law.pace.edu/cases/061030sb.html.

9. Foreign Trade Court of Arbitration attached to the Serbian Chamber of Commerce, Serbia, 15 July 2008, at $\S 6$, available at http://cisgw3.law.pace.edu/cases/080715sb.html.

10. Milena Djordjevic \& Vladimir Pavic, The CISG in the Balkans, paper presented at the University of Florida Center for International Business Education \& Research/Warrington College of Business Administration Conference: Global Challenges of International Sales Law (November 11-12, 2011) (on file with author). 
diplomatic conference did not find commonality, they deferred the issue of penalty clause expressed as a fixed sum to Article 4, the validity article, as there is no direct reference within the CISG in relation to penalty clauses. On this point, the opinions of this author and Professor Graves are not divergent.

There is no argument that a fixed sum (liquidated damages) is governed by the CISG. The real argument boils down to one question: when does a fixed sum become a penalty clause and cease to be a fixed sum and hence could be governed by domestic law or as it is argued in this article is still governed by the CISG? Simply put, parties in most cases will only be able to make a distinction between a fixed sum and a penalty clause once the contract is broken. It can be argued therefore that from a theoretical point of view the tenets of the economic analysis of law are helpful as they indicate that rational contracting parties will negotiate efficient contract terms, ${ }^{11}$ which suggests that parties do understand their obligations when agreeing on a fixed sum. As there is agreement it follows that courts ought to uphold the bargains entered into by contractual parties.

This article will provide arguments to support the contention that the CISG includes a general principle that allows the inclusion of fixed sums into the sphere of the CISG without enlivening Article 4. In order to overcome the argument of Professor Graves, two hurdles need to be overcome.

First, there is an argument that would suggest that a clause once valid and governed by the CISG cannot become invalid as the time of determination as to its validity remains at the time of conclusion of the contract. The second point is whether Article 6 is to be enlivened before Article 4 becomes an issue. The point is that — as the fixed sum is included into the contract - the validity issue is not enlivened; hence a partial or total deviation from the CISG is operational. Simply put, only upon breach or after the breach does it become obvious that the fixed sum is a "liquidated sum" or a penalty clause. Hence the question can be rephrased as: at what stage of the contractual relationship is the determinative point to see whether a validity issue arises?

\section{FIRST ARGUMENT}

The following situations need to be explored in order to fully understand the interplay of general principles and provisions of the CISG. First, a fixed sum included in the contract is below or at the actual amount of damages.

11. Larry A. Dimatteo \& Daniel T. Ostas, Comparative Efficiency in International Sales Law, 26 AM. U. InT'L L. Rev. 371, 395 (2011). 
Secondly, a fixed sum, though judged to be equal to or below the actual damages at the formation of the contract, proves to be too high at the breach of the contract and could not be termed penal in nature.

It is uncontested that parties to a contract can "derogate from or vary the effects of any of its provisions." 12 If a party included a fixed sum into a contract as being the totality of damages, which are due in case of a breach of contract, the matter would be governed by the CISG. The main argument would hinge on Article 74, as damages consist of a "sum equal to the loss including loss of profit suffered by the other party." The argument of the breaching party is simple. They would argue that by including a fixed sum the parties have derogated from the CISG, namely Article 74. In effect they have fixed a sum, which described the amount that can be claimed as damage. If the fixed sum is less or the same as the actual loss, the argument stands uncontested as there is no validity issue in any legal system. The contract has allocated the damages and the only question is whether a party that underestimated the losses can claim the difference under the CISG. It is argued that the party suffering the loss cannot claim any extra damages, otherwise freedom of contract, which is implied in Article 6 of the CISG, would be violated.

After all, a contractual clause is always upheld unless it is in breach of a mandatory law, hence derogation is not possible. Article 74 does indicate that damages need to be "equal"13 to the loss and importantly in sentence two the restriction is that it cannot "exceed the loss which the party in breach foresaw." ${ }^{\prime 4}$ Arguably sentence one needs to be read first which indicates that the sum needs to be equal to the loss but by including a fixed sum, Article 74 has been derogated from. The question is whether the contractual term derogated the whole of Article 74 or only parts thereof. The answer is obviously that sentence one has only been replaced via Article 6 by a contractual term. The fixed sum not being a penalty clause does not enliven Article 4 even taking Professor Graves's arguments into consideration. It is therefore inconceivable that a court would change or vary a clause as "performance would be so radically changed as to amount to the performance of an obligation quite different from that contemplated by the contract." 15

\footnotetext{
12. United Nations Convention on Contracts for the International Sale of Goods art. 6, U.N. Doc. A/CONG.97/18, Annex 1 (Apr. 11, 1980) [hereinafter CISG].

13. CISG art. 74.

14. Id.

15. Peter Schlechtriem, Uniform Sales Law-The UN-Convention on Contracts for the International Sale of Goods 104 (Manz 1986), available at http://www.cisg.law.pace.edu/cisg/biblio/
} 
Professor Graves argues that using sentence two only amounts "to the use of the tail (foreseeability) to wag the dog (compensation for the aggrieved party's expectation damages). Instead one should begin any analysis of Article 74 with its first sentence." the contract Article 6 in effect varied Article 74 by replacing sentence one with a fixed sum. If Professor Graves's argument is correct then it would only be relevant if Article 4, at the time of the breach, is superior to Article 6 . However, this argument presupposes the fact that at the formation of the contract the validly clause has been operative, that is, there is no functionally equivalent solution within the CISG. To invoke Article 4 just because the contract contains a fixed sum would mean that not only is Article 6 relegated but also that Article 4 now replaces a functionally equivalent solution, which pursuant to Article 7(1) would replace the operation of Article 4. Besides, to ask for a lesser sum as damages does not enliven an argument of validity.

Simply put, the interpretation of the interplay between Article 6 and 74 is illustrated by the fact that if a fixed sum is less than the actual damages, the party who suffers the loss cannot rely on Article 74 first sentence, as it is now replaced by the contractual clause. Sentence two illustrates that the damages "may not exceed the loss which the party in breach foresaw or ought to have foreseen at the time of the conclusion of the contract." The breaching party is only liable for the damages they foresaw at the conclusion of the contract, which is the fixed amount and not the damages which can eventuate at the time of the breach of the contract. This conclusion is helped by the fact that the first two words in sentence two, namely "such damages," are to be interpreted as meaning the damages as fixed in the contract. There is no other solution possible, as sentence one is not operative anymore due to Article 6 . It must be remembered that any court will always look at the contract first and only if the contract is silent on an issue will the CISG be consulted. It is argued, therefore, that the inclusion of a fixed sum in effect varies part of Article 74; the limit of damages is not set by Article 74 but by the contractual clause.

Another situation needs to be analysed: where the fixed sum is equal to the loss when the contract was formed, but when the contract is breached the actual damages are far less then the fixed sum and arguably a party might now contend that the damages amount to a penalty. It is uncontested that at the formation of the contract, Article 4 is not applicable as the fixed sum is not

schlechtriem.html\#a18 (citing ULIS Article 74(2)).

16. Graves, supra note 1, at 161 . 
penal in nature. The question is: when is Article 4 enlivened? It is clear that at the formation stage the CISG governs the objective requirement; that is the external consensus. But concerning issues of validity of the contract, the internal consensuses are "with few exceptions explicitly excluded from the domain of the Convention." "It is also recognised that any deviation from the convention by Article 6 is subject to the "validity check" of Article $4 .{ }^{18}$ The most common issues of validity concern matters of mistake, fraud and illegality. All of these issues arguably are discoverable at the formation stage and not when the contract is breached. Arguably, therefore, in relation to the inclusion of a fixed sum, validity is not an issue at the formation stage and hence Article 6 is the "master" of the contract and therefore "the interpretation of "validity' is not initially a question of domestic law." 19

Professor Graves argued, at least by implication, that the relevant point of inquiry is at the time of the breach of the contract as the clause has now become invalid, hence domestic law will resolve the issue. However, this view does not take Article 8 or Article 74 into consideration. Article 74 clearly notes that the damages must have been foreseen or ought to have been foreseen by the breaching party at the time of the conclusion of the contract. ${ }^{20}$ Article 8 backs up Article 74 as the conduct of the parties - in this case agreeing on fixed sum - must be interpreted "according to the understanding that a reasonable person of the same kind as the other party would have had in the same circumstances." 21 Article 74 by these very words focuses on knowledge at the time when the contract is concluded and not when it is breached, hence Article 4 is not enlivened.

The conclusion is that a functionally equivalent principle has been created and to extend the validity issue from the "internal consensus" to the "external consensus" is to be rejected, as it is not within the sphere of influence of Article 4. Simply put, the question of validity needs to be asked at the formation stage and not when the contract is breached.

The argument that the formation stage is the crucial point when the validity issue needs to be determined is strengthened when the allocation of risk is investigated. It is argued that in general-and specifically in this case - the amount of damages in cases of breach and the risk of payment of a fixed sum rests with the party who accepts the terms. In the absence of

17. Djordjevic, supra note 5, at 65.

18. Id.

19. Id.

20. CISG art. 74.

21. CISG art. 8(2). 
contractual limitations, it has to be established that at the time when the contract was formed, the party who has taken the risk could have controlled the event that resulted in the breach. Hence, a party breaching a contract does so with perfect knowledge of how much the costs of the breach are.

If, on the other hand, the breaching party couldn't have controlled the event which made the performance of the contract impossible, the breaching party can rely on Article 79. A Belgian court noted:

The Commercial Court of Hasselt has ruled that changes in prices are foreseeable and do not exempt the parties from performance of their obligations. The court stated, moreover, that the performance of the obligation in such a case would imply a financial loss, but that this did not prevent the performance of the agreement. The conclusion of a contract that is not lucrative or that is even a losing proposition is part of the risks that belong to commercial activities ... ${ }^{22}$

The question of risk - in this case the cost of breaching the contract - is important because in reality it is only the party who assumed the risk that has an interest and the ability to control the risk. Schlechtriem stated that:

It is a question of an allocation of risk of damages based on economic reasons and not only on the basis of control over the sphere in which damages could arise. ${ }^{23}$

The conclusion is that:

CISG art. 79 does not entitle the promisor to be released from his contractual obligations due to change of the economic background on which the parties relied for the conclusion of the contract. ${ }^{24}$

If that is the case, then it can be argued that a fixed sum is a change of the economic background on which the parties relied and hence the measurement of risk and its allocation is taking place at the conclusion of the contract and not at the time of the breach. Therefore all foreseeable consequences of a breach such as the payment of a fixed sum fall under the risk of the breaching party. Only those risks that could not have been reasonably anticipated fall

22. Rechtbank van Koophandel Tongeren [District Court of Tongeren] Belgium, 25 Jan. 2005, available at $\mathrm{http}: / /$ cisgw3.law.pace.edu/cases/050125b1.html.

23. Peter Schlechtriem, Uniform Sales Law in the Decision of the Bundesgerichtshof, in 50 YeARS of the Bundesgerichtshof [Federal Supreme Court of Germany]: A Celebration Anthology FROM THE ACADEMIC COMMUNITY (Todd J. Fox trans., 2001), available at http://www.cisg.law.pace.edu/ cisg/biblio/schlechtriem3.html.

24. Efeteria Lamias [Court of Appeals of Lamia] Greece, 2006, available at http://cisgw3.law .pace.edu/cases/060001gr.html. 
under Article 79, which certainly are not the cost associated with a breach of a contract. It is therefore obvious that the question of risk and particularly what type of risk needs to be understood. The Federal Supreme Court of Germany clarified the situation by stating:

The possibility of exemption under CISG Art. 79 does not change the allocation of the contractual risk. ... [and upon breach needs to pay damages which are already fixed in the contract]. ${ }^{25}$

Arguably, therefore, as the risk has passed irrespective whether the fixed sum is under, at or even possibly above the actual damages under an Article 79 exemption, the fixed sum cannot be claimed. In sum, the two situations where a breach occurs damages are still possible, but under Article 79-as it is an exemption - the damages are quarantined.

So far it has been demonstrated that a fixed sum that is not greater than the actual damages can be enforced. This proposition appears to be accepted in all legal systems and can be accommodated within the CISG. If the fixed sum is the same as the damages when the contract has been concluded, but turns out to be greater at the breach, such a sum can still be enforced, because the critical point when the validity issues must be decided is at the formation stage of the contract and not at the breach.

This conclusion is certainly strengthened when looking at Article 79, which clearly notes that the exemption is judged on facts that were known at the time of the conclusion of the contract. Article 79 only quarantines damages that are due to an impediment and therefore not known at the conclusion of the contract. This does not include the fixed sum that was known at the conclusion of the contract.

The most important point is that the focus to establish a "functionally adequate solution" is when the contract is formed and not when it is breached. The outcome is that Article 4 is not applicable.

\section{SECOND ARGUMENT}

The real problem arises when the fixed sum is judged to exceed the actual damages at the conclusion of the contract. Two possible issues can arise: first, the parties are not aware of it and second, the parties are aware that the fixed sum is in fact a penalty clause. Because the fixed sum is greater than the loss,

25. Bundesgerichtshof [Federal Supreme Court] Germany, 24 Mar. 1999, available at http:// cisgw3.law.pace.edu/cases/990324g1.html. 
the question of validity is enlivened and hence, as Professor Graves might argue, the penalty clause is deemed to be invalid and hence is excluded from the CISG. As pointed out above, any fixed sum must be interpreted at the formation stage of a contract and hence that is also the point where logically the question of validity should be judged. In order to assist in ascertaining the parties' intentions, Article 8 is of help and logically if the parties knew or ought to have known that the fixed sum is penal in nature, the issue of validity must now be considered.

Professor Graves has argued that when the fixed sum is a penalty clause and the parties are aware of this the issue is clear. Article 74 and 8 point to the fact that Article 4 is now enlivened. It is therefore clear that Article 6 is subject to the validity check and in this case the penalty clause is deemed to be invalid.

Of all the possible cases, this is arguably the only situation where the application of Article 4 is arguably possible specifically when both parties were aware that the fixed sum is penal in nature.

In this case a complex situation arises. First, Article 7 mandates uniformity. Fixed sums that turn out to be penal in nature are enforced in civil law countries and not are not generally enforced in common law countries. Also, following the above argument, a fixed sum which turns out to be penal only at the breach and not at the formation stage, must not be enforced; the result is that no uniformity is achieved.

The second issue is that Article 6 allows for derivation and Article 8 invites the courts to investigate the intent of the parties, which in these cases shows that they are willingly and knowingly entering into a contract where a clause is penal in nature. It is now that Article 4, despite the above principles, changes an otherwise agreed bargain by domestic interference. Looking at the totality of principles within the CISG, it would appear that a further general principle can be constructed, namely the principle that fixed sums are what they are meant to be, a re-calculation of damages, negating at least part of Article 74, namely sentence one and hence a contractual obligation founded within the four corners of the CISG. The question is why a court should reward a party, which by their own free will entered into a bargain that in the end proved to be economically not advantageous. Considering that hardship is not within the CISG, it could be argued that a penal sum falls under the principle of hardship and hence a court should enforce a contractual bargain and apply the spirit of the CISG and not the technical application of one article. The "mercantile" rather than a "promissory" perspective ought to direct courts and tribunals to read the CISG within its four corners and the weight of principles pointing to the fact that a bargain must be upheld is an 
overwhelming one and a fixed sum is a fixed sum and should be judged a calculation of "real damages" and the actual amount of the fixed sum is irrelevant. The parties have decided what the real costs of a breach are and such a decision must be enforced. Furthermore, it can be argued that the CISG has no promissory principles that are applicable when determining damages.

\section{CONCLUSION}

It is uncontested that, as clearly noted in sentence one, Article 4 "governs only the formation of the contract of sale and the rights and obligations of the seller and the buyer arising from such a contract." ${ }^{26}$ It follows therefore that the contract or any clauses in a contract that are invalid ab initio under any domestic law must be evaluated taking the particular domestic laws into consideration and not the CISG. As Professor Graves correctly noted they include issues such as illegality. ${ }^{27}$ It is therefore argued that the formation of the contract is the determinative point in time where the decision needs to be made whether Article 4 is applicable. However, where there is a functionally equivalent principle or provision within the CISG, Article 4 does not apply. It is argued that if at the formation of the contract a functionally equivalent principle can be found, Article 4 cannot be invoked. Simply put, the point of assessment is not the point where the breach occurred, but at the time the contract was formed.

It has been argued that the starting and finishing points for any argument is the formation of a contract. The promises made at the formation of the contract should be paramount and any other intervening events, such a breach of a contract, must be judged by the original contract with a view that the parties entered into a contract willingly knowing the consequences of any nonperformance. As an observation, a party entering into a contract willingly and knowingly signing the contract and understanding that a penalty clause is embedded in the contract can later escape the clause claiming invalidity of the term.

It is argued that the aggrieved party is now disadvantaged and without redress except claiming the damages as calculated at the breach of the contract by the court or tribunal. Graves correctly understands that the argument in effect uses the "functional equivalent test" as the term is used in Article 4. He goes on to argue that using Article 74 amounts "to the use of the 'tail'

26. CISG art. 4.

27. Graves, supra note 1, at 157. 
(foreseeability) to 'wag the dog' (compensation for the aggrieved party's expectation damages). Instead one should begin any analysis of Article 74 with its first sentence." 28

This indeed is a good argument, however, the real question is: how is Article 6 interpreted? The article clearly indicates that a party can either derogate from any provision, but most importantly it can also vary the effects of any of its provisions. By varying a provision - in this case Article 74-the parties varied the effect of Article 74 namely excluding sentence one. The parties in effect have stated that the damages are capped by the stated fixed sum and not by the "sum equal to the loss." 29 If Article 6 would not be able to vary the effect of Article 74, then the argument of Graves that the awarding of "punitive damages in excess of a party's actual loss is contrary to the basic principle of Article 74" would be correct. However, Article 6 has changed the effects of Article 74, which still mandates that the losses must have been foreseen at the time of the conclusion of the contract and most importantly the breaching party must have known the possible consequences of the breach. The stipulation that facts must be known or foreseen at the conclusion of the contract is not unique to Article 74. It can also be found as an example in Article 79.

In sum, a court should view a fixed sum as a predetermined amount of damages payable in cases of a breach of contract. The fact that in some cases the amount might exceed actual damages is of no consequence and is not subject to the validity issue. The fixing of a sum is a calculation of damages which the parties knew or ought to have know when the formed the contract. Perhaps the last word should belong to Peter Schlechtriem who noted:

Article 6 guarantees party autonomy over both the conflict rules and the substantive law; [thus], any rule of the Convention can be altered or rejected by the parties, even by standard contract terms $\mathrm{s}^{30} \ldots$. [and importantly] the underlying idea is that the parties, at the conclusion of the contract, should be able to calculate the risks and potential liability they assume by their agreement. ${ }^{31}$

\footnotetext{
28. Id. at 161 .

29. CISG art. 74.

30. Schlecthriem, supra note 15 , at 34 .

31. Id. at 96 .
} 